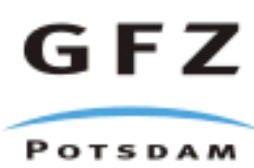

Originally published as:

Yancheva, G., Nowaczyk, N. R., Mingram, J., Dulski, P., Schettler, G., Negendank, J. F. W., Liu, J., Sigman, D. M., Peterson, L. C., Haug, G. H. (2007): Influence of the intertropical convergence zone on the East Asian monsoon. - Nature, 445, 7123, 74-77,

DOI: 10.1038/nature05431. 


\title{
Influence of the intertropical convergence zone on the East Asian monsoon
}

Gergana Yancheva ${ }^{1}$, Norbert R. Nowaczyk ${ }^{1}$, Jens Mingram ${ }^{1}$, Peter Dulski ${ }^{1}$, Georg Schettler ${ }^{1}$, Jörg F. W. Negendank ${ }^{1}$, Jiaqi Liu ${ }^{2}$, Daniel M. Sigman ${ }^{3}$, Larry C. Peterson ${ }^{4}$ and Gerald H. Haug $^{1}$

1. GeoForschungsZentrum (GFZ), Section 3.3, Telegrafenberg, Potsdam D-14473, Germany

2. Institute of Geology and Geophysics, Chinese Academy of Sciences, PO Box 9825, Beijing 100029, China

3. Department of Geosciences, Princeton University, Princeton, New Jersey 08544, USA

4. Rosenstiel School of Marine and Atmospheric Science, University of Miami, Miami, Florida 33149, USA

Correspondence to: Gerald H. Haug ${ }^{1}$ Correspondence and requests for materials should be addressed to G.H.H. (Email: haug@gfz-potsdam.de).

\begin{abstract}
The Asian-Australian monsoon is an important component of the Earth's climate system that influences the societal and economic activity of roughly half the world's population. The past strength of the rain-bearing East Asian summer monsoon can be reconstructed with archives such as cave deposits ${ }^{1,2,3}$, but the winter monsoon has no such signature in the hydrological cycle and has thus proved difficult to reconstruct. Here we present high-resolution records of the magnetic properties and the titanium content of the sediments of Lake Huguang Maar in coastal southeast China over the past 16,000 years, which we use as proxies for the strength of the winter monsoon winds. We find evidence for stronger winter monsoon winds before the Bølling-Allerød warming, during the Younger Dryas episode and during the middle and late Holocene, when cave stalagmites suggest weaker summer monsoons ${ }^{1,2,3}$. We conclude that this anticorrelation is best explained by migrations in the intertropical convergence zone. Similar migrations of the intertropical convergence zone have been observed in Central America for the period ad 700 to 900 (refs 4-6), suggesting global climatic changes at that time. From the coincidence in timing, we suggest that these migrations in the tropical rain belt could have contributed to the declines of both the Tang dynasty in China and the Classic Maya in Central America.

Instrumental and historical records reaching back several centuries show considerable interannual to decadal variability in monsoonal strength. Although El Niño warm events tend to weaken the summer rainfall in both the Indian and East Asian monsoons ${ }^{7}$, the instrumental data do not reveal a straightforward relationship among these major climate elements ${ }^{8}$. Palaeoclimate records can provide additional insights into monsoon dynamics, as the past includes larger amplitudes of climate change that may reveal more robust linkages. Previous palaeoclimate reconstructions generally agree that the Asian summer monsoon was weaker during cold phases in the Northern Hemisphere ${ }^{1,2,3,9,10,11,12,13,14,15}$, when the intertropical convergence zone (ITCZ) tends to move southward ${ }^{16,17,18}$, as it does during El Niño years ${ }^{19}$, 20, 21 .
\end{abstract}


Here we present a new palaeoclimatic record with nearly annual time-resolution from a

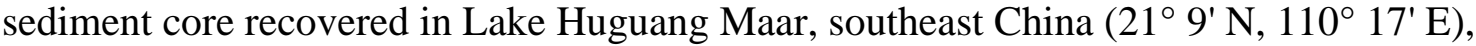
which extends back to $16.2 \mathrm{kyr}$ ago (Fig. 1). The sedimentation rates range from $41 \mathrm{~cm} \mathrm{kyr}^{-1}$ before the Bølling-Allerød to $112 \mathrm{~cm} \mathrm{kyr}^{-1}$ during the past 4,000 yr. The age model is based on 5 AMS (accelerator mass spectrometry) ${ }^{14} \mathrm{C}$ dates of leaves and 4 of bulk sediment, with dating errors of less than $\pm 160 \mathrm{yr}$ within the $1 \sigma$ interval of the AMS ${ }^{14} \mathrm{C}$ method. Adjustments using the well-dated records from Cariaco basin are within the error of the original ${ }^{14} \mathrm{C}$-based age model (Fig. 1; see also Supplementary Information). Lake Huguang Maar today lies $23 \mathrm{~m}$ above sea level and has a water depth of $20 \mathrm{~m}$. The surface area of the lake is $2.25 \mathrm{~km}^{2}$, and it drains an extremely small catchment of $3.2 \mathrm{~km}^{2}$. Because of its small catchment and a lack of stream inputs, the lake receives a minimal quantity of material by runoff and thus acts as a natural sediment trap for dust delivered to the site by the northerly winds of the winter monsoon. The Huguang Maar sediments record the strength of the winter monsoon in two independent ways: (1) the accumulation of wind-blown material, and (2) the redox-sensitive characteristics and total organic carbon (TOC) content of the sediment as a result of changes in wind stress and water-column mixing.

Our palaeoclimate time series are based on continuous measurements of sediment elemental composition and magnetic susceptibility, augmented by discrete measurements of additional magnetic properties and TOC content (Fig. 1). Micro X-ray fluorescence element scanning was performed at a resolution of $0.5 \mathrm{~mm}$, smoothed with a 9 point triangular window. Magnetic susceptibility was measured in $2.5 \mathrm{~mm}$ steps directly on the surface of the split core halves. Additionally, sediment slices of $4 \mathrm{~mm}$ thickness (for the time interval of Termination I and the early Holocene) were analysed for their rock magnetic properties (see Methods).

Two rock magnetic parameters, magnetic susceptibility and the S-ratio (Fig. 1), measure the concentration of magnetic minerals and the mean oxidation state of iron in those minerals, respectively. The S-ratio is a (nonlinear) estimate of the abundance of magnetite compared to that of antiferromagnetic minerals, mainly haematite ${ }^{22}$. In Lake Huguang Maar, a high S-ratio indicates the availability of bottom water oxygen, and it is interpreted to reflect wind-driven lake mixing. Magnetic susceptibility is sensitive to both lake redox conditions and the aeolian input, both of which are affected by wind strength (see Methods).

The Ti content of the sediment is used to reconstruct the aeolian input into the lake (Fig. 1). The main lithogenic source to Huguang Maar sediments is dust transported by the winter monsoon winds from the arid areas in the north-for example, the loess plateau-and possibly local sources. Changes in Ti are interpreted as a measure of winter monsoon winds, with stronger winds more effectively transporting dense Ti- and Fe-rich grains (including the magnetic minerals) over the lake. Ti (rather than Fe) is used here as the dust input indicator because of its lack of redox sensitivity; however, the two are highly correlated (data not shown).

During cold climates, for instance, before $14.8 \mathrm{kyr}$ ago and during the Younger Dryas (between 12.8 and 11.6 kyr ago), Ti content, magnetic susceptibility and S-ratio are high (Figs $1,2)$ while TOC content is low ${ }^{23}$. In contrast, during the Bølling-Allerød and early Holocene (before $7.8 \mathrm{kyr}$ ago), Ti content and rock magnetic amplitudes drop, and TOC increases (Fig. 1). Over the course of the Holocene, magnetic susceptibility clearly increases while the $\mathrm{Ti}$ content shows a weaker trend towards higher values; over this same time interval, the TOC content decreases (Fig. 1). 
The sediment S-ratio and TOC content, which indicate changes in bottom water oxygen, are functionally independent from Ti content, an indicator of dust input. Thus, their interconsistency, reflecting high lake mixing whenever Ti-rich dust input is high, makes a compelling case for interpreting these records as a robust measure of winter monsoon strength. We deduce that the pre-Bølling-Allerød, the Younger Dryas, and the later Holocene were all characterized by strong winter monsoons in East Asia. During those intervals, low TOC content and higher magnetic susceptibility and S-ratios indicate enhanced wind mixing of the lake's waters, resulting in a well oxygenated lake floor, good preservation of magnetic minerals, and increased degradation of organic matter. In parallel, the higher Ti content during these times suggests intensified winter winds in central China leading to an increased input of dense Ti-bearing dust. In contrast, during periods of warmer climate such as the Bølling-Allerød and the early Holocene, Ti concentrations are lower, while lower magnetic susceptibility and S-ratios are coupled with higher TOC content, implying reduced winter monsoon winds and stable stratification of the lake.

The Lake Huguang Maar records of winter monsoon strength show a remarkable relationship with the radiometrically dated $s^{18} \mathrm{O}$ records from stalagmites at Dongge cave ${ }^{2,3}$ and Hulu cave $^{1}$, East Asia (Fig. 2). Strong winter monsoon phases reconstructed from Huguang Maar correlate with higher ${ }^{18} \mathrm{O}$ at Hulu and Dongge caves, which indicates lower summer precipitation rates and thus a weaker summer monsoon ${ }^{1}$. Thus, our data, when compared with the speleothem ${ }^{1,2}$ and South China Sea ${ }^{24}$ records, argue for an inverse correlation between the strengths of the winter and summer monsoons (see also Supplementary Information).

Moreover, the similarity of the records implies that monsoon changes during the latest glacial, Bølling-Allerød, Younger Dryas and Holocene were synchronous and common to large regions of coastal Southeast Asia. The inverse correlation between summer and winter monsoons recognized here is also evident for the Indian monsoon system, with the Younger Dryas representing a time of weaker summer and stronger winter monsoons ${ }^{10}$. The highresolution records from East Asia indicate that this summer/winter monsoon anti-correlation also applies on shorter timescales (Fig. 2).

Migration of the annual mean position of the ITCZ provides a single coherent explanation for the observed trends in both winter and summer monsoons over the past $16 \mathrm{kyr}$, as well as for the strong anti-correlation between them. When the ITCZ is displaced northward, the summer monsoon should strengthen, while the winter monsoon will weaken. A northward shift in the ITCZ would be expected during times of Northern Hemisphere warming ${ }^{25}$, such as the Bølling-Allerød and the early Holocene, times when, indeed, the East Asian summer monsoon was strong ${ }^{1,26}$ and the winter monsoon was weak. This mode of explanation for climate change has recently proven fruitful for interpreting palaeoclimate records from the tropical Americas $^{17,18}$ (Fig. 2; see also Supplementary Information). The data reported here, in concert with existing data ${ }^{1,2,3,20,21,27}$, suggest that these ITCZ migrations extended across the Pacific.

The role of climate and environmental change in the success or failure of societies is a matter of intense debate ${ }^{4,28,29}$. It would be simplistic to imagine that all episodes of societal change are driven by climatic events, especially in an advanced and complex society such as dynastic China. Nevertheless, we note that, on the basis of our new Huguang Maar data, major changes in Chinese dynasties ${ }^{30}$ occurred when the winter monsoon was strong (Fig. 3). The anticorrelation between winter and summer monsoon strength indicated by comparison of the Huguang Maar data with the cave records would suggest that dynastic transitions tended to 
occur when the summer monsoon was weak and rainfall was reduced. Dynastic changes in China often involved popular uprisings during phases of crop failure and famine, consistent with a linkage to reduced rainfall. The Tang dynasty has been described as a high point in Chinese civilization $^{30}$, a golden age of literature and art. The power of the dynasty began to ebb in the eighth century, starting with a defeat by the Arab army in ad 751. Rebellions further weakened the Tang empire, and it fully collapsed in ad 907 (ref. 30).

It is intriguing that the rise and collapse of the Classic Maya ${ }^{4,5}$ coincided with the golden age and decline of the Tang dynasty in China ${ }^{30}$. Comparison of the Ti records from Lake Huguang Maar and the Cariaco basin reveals similarities, including both a general shift towards drier climate at about ad 750 and a series of three multi-year rainfall minima within that generally dry period (Fig. 3), the last of which coincides with the final stage of Maya collapse as well as the end of the Tang dynasty. Given these results, it seems possible that major circum-Pacific shifts in ITCZ position catalysed simultaneous events in civilizations on opposite sides of the Pacific Ocean.

\section{Methods}

\section{X-ray and magnetic measurements}

Element scanning was carried out with a micro X-ray fluorescence spectrometer EAGLE BKA (Röntgenanalytik Meß̈technik GmbH). Isothermal remanent magnetizations (IRM), saturation as well as back field, were imprinted with a 2G Enterprises pulse magnetizer in magnetic fields of $2 \mathrm{~T}$ and $-0.3 \mathrm{~T}$, respectively. All IRMs were measured on a Molyneux spinner magnetometer (Minispin). The S-ratios were calculated after ref. 22. Continuous logging of magnetic susceptibility was performed with a Bartington MS2E sensor directly on the surface of split core halves. Magnetic susceptibility of the discrete samples was measured with a Kappabridge KLY-3S (AGICO).

\section{S-ratio and TOC}

The S-ratio varies between 0 for pure haematite and 1 for pure magnetite ${ }^{22}$. A high S-ratio indicates a predominance of oxic sedimentary conditions and the preservation of magnetite ${ }^{22}$. The strong correlation between high S-ratio and low TOC in our record has two alternative interpretations: (1) the supply of oxygen to the sediments is high, or (2) the flux of organic matter to the lake bottom is low. In the pervasively eutrophic Lake Huguang Maar, large changes in productivity are unlikely and difficult to cause by climate change. Thus, the measured changes in S-ratio and TOC are most logically interpreted as the result of winddriven lake mixing, with more mixing and thus higher S-ratio and lower TOC occurring during times of strong winter monsoon winds. This interpretation is supported by sedimentary manganese and biogenic opal concentrations and accumulation rates (see Supplementary Information).

\section{Magnetic susceptibility}

The sharp increase in magnetic susceptibility at $\approx 7.8 \mathrm{kyr}$ ago, which is simultaneous with a saturating increase in S-ratio and a decrease in TOC content, requires that increasing wind mixing caused a threshold in lake oxygen content to be crossed, such that magnetite is subsequently preserved in the sediments (Supplementary Fig. 4). However, the continued 
gradual increase in magnetic susceptibility over the mid- to late Holocene has two potential explanations. It may result from a continued increase in the annual mean oxygen content of the lake, due to a continued increase in wind mixing. In this case, the lack of change in S-ratio would be due to saturation of this index at a value close to 1 (Supplementary Fig. 4).

Alternatively, the gradual increase in magnetic susceptibility may result from an increase in the aeolian delivery of magnetic minerals because of stronger winter winds, as magnetic minerals such as magnetite are much (roughly two times) denser than most aluminosilicates. The gradual decrease in TOC content through the mid- to late Holocene may indicate either an increasing wind-driven ventilation of the lake or progressively greater dilution by aeolian inputs. In either case-an increase in lake mixing and/or an increase in aeolian input- the combined data require a Holocene strengthening of the winter monsoon.

\section{References}

1. Wang, Y. J. et al. A high-resolution absolute-dated Late Pleistocene monsoon record from Hulu Cave, China. Science 294, 2345-2348 (2001)

2. Yuan, D. et al. Timing, duration, and transitions of the Last Interglacial Asian Monsoon. Science 304, 575-578 (2004)

3. Dykoski, C. A. et al. A high-resolution, absolute-dated Holocene and deglacial Asian monsoon record from Dongge Cave, China. Earth Planet. Sci. Lett. 233, 71-86 (2005)

4. Diamond, J. Collapse (Penguin, London, 2005)

5. Fagan, B. Floods, Famines and Emperors: El Nino and the Fate of Civilizations (Pimlico, London, 2000)

6. Haug, G. H. et al. Climate and the collapse of Maya civilization. Science 299, 17311735 (2003)

7. Kumar, K. K., Rajagopalan, B. \& Cane, M. A. On the weakening of the relationship between the Indian monsoon and ENSO. Science 284, 2156-2159 (1999)

8. Wang, B. The Asian Monsoon (Springer, Berlin, 2006)

9. Thompson, L. G. et al. Tropical climate instability: the last glacial cycle from a Qinghai-Tibetan ice core. Science 276, 1821-1825 (1997)

10. Sirocko, F., Garbe-Schonberg, D., McIntyre, A. \& Molfino, B. Teleconnections between the subtropical monsoons and high-latitude climates during the last deglaciation. Science 272, 526-529 (1996)

11. Heslop, D. et al. Sub-millennial scale variations in East Asian monsoon systems recorded by dust deposits from the North-Western Chinese loess plateau. Phys. Chem. Earth 24, 785-792 (1999)

12. Porter, S. C. \& An, Z. Correlation between climate events in the North Atlantic and China during the last glaciation. Nature 375, 305-308 (1995)

13. Oppo, D. W. \& Sun, Y. Amplitude and timing of sea-surface temperature change in the northern South China Sea: Dynamic link to the East Asian monsoon. Geology 33, 785-788 (2005)

14. Liu, T. \& Ding, Z. Chinese loess and the paleomonsoon. Annu. Rev. Earth Planet. Sci. 26, 111-145 (1998)

15. Ding, Z., Rutter, N., Han, J. \& Liu, T. A coupled environmental system formed at about 2.5 Ma in East Asia. Palaeogeogr. Palaeoclimatol. Palaeoecol. 94, 223-242 (1992)

16. Hughen, K. A., Overpeck, J. T., Peterson, L. C. \& Trumbore, S. Rapid climate changes in the tropical Atlantic region during the last deglaciation. Nature 380, 51-54 (1996) 
17. Haug, G. H., Hughen, K. A., Sigman, D. M., Peterson, L. C. \& Röhl, U. Southward migration of the Intertropical Convergence Zone through the Holocene. Science 293, 1304-1308 (2001)

18. Wang, X. et al. Wet periods in northeastern Brazil over the past $210 \mathrm{kyr}$ linked to distant climate anomalies. Nature 432, 740-743 (2004)

19. Cane, M. A. The evolution of El Nino, past and future. Earth Planet. Sci. Lett. 230, 227-240 (2005)

20. Koutavas, A. \& Lynch-Stieglitz, J. Marchitto Jr, T. M. \& Sachs, J. P. El Nino-like pattern in ice age tropical Pacific sea surface temperature. Science 297, 226-230 (2002)

21. Ivanochko, T. S. et al. Variations in tropical convection as an amplifier of global climate change at the millennial scale. Earth Planet. Sci. Lett. 235, 302-314 (2005)

22. Bloemendal, J., King, J. W., Hall, F. R. \& Doh, S. J. Rock magnetism of Late Neogene and Pleistocene deep-sea sediments: Relationship to sediment source, diagenetic processes and sediment lithology. J. Geophys. Res. 97, 4361-4375 (1992)

23. Mingram, J. et al. The Huguang maar lake - a high-resolution record of palaeoenvironmental and palaeoclimatic changes over the last 78,000 years from South China. Quat. Int. 122, 85-107 (2004)

24. Wang, L. et al. East Asian monsoon climate during the Late Pleistocene: highresolution sediment records from the South China Sea. Mar. Geol. 156, 245-284 (1999)

25. Hastenrath, S. \& Greischar, L. Circulation mechanisms related to northeast Brazil rainfall anomalies. J. Geophys. Res. 98, 5093-5102 (1993)

26. Wang, L. et al. Holocene variations in Asian monsoon moisture: a bidecadal sediment record from South China Sea. Geophys. Res. Lett. 26, 2889-2892 (1999)

27. Fleitmann, D. et al. Holocene forcing of the Indian Monsoon recorded in a stalagmite from Southern Oman. Science 300, 1737-1739 (2003)

28. deMenocal, P. B. Cultural responses to climate change during the late Holocene. Science 292, 667-673 (2001)

29. Hodell, D. A., Brenner, M., Curtis, J. H. \& Guilderson, T. Solar forcing of drought frequency in the Maya lowlands. Science 292, 1367-1370 (2001)

30. Blunden, C. \& Elvin, M. Cultural Atlas of China (Checkmark Books, New York, 1998)

\section{Acknowledgements}

We thank M. Cane, R. Seager, P. deMenocal and S. Clemens for discussions, comments and reviews. This work was supported by the Deutsche Forschungsgemeinschaft (DFG). D.M.S. and G.H.H. thank the Humboldt Foundation for support. D.M.S. was also supported by BP and Ford Motor Company through the Princeton Carbon Mitigation Initiative. 
Figure 1: Palaeoclimate time series of Lake Huguang Maar.

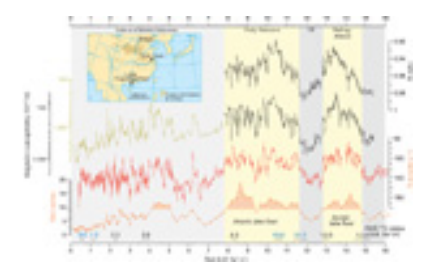

Rock magnetic parameters (magnetic susceptibility and S-ratio), and Ti and TOC content from the sediment sequence during the past $16 \mathrm{kyr}$. Distinct intervals of anoxic conditions at the lake bottom are shaded in yellow. The S-ratio is saturated at 1 after $7.8 \mathrm{kyr}$ BP. Five AMS ${ }^{14} \mathrm{C}$ dates of leaves (black) and four of bulk sediment (blue) are shown with an uncertainty interval of $2^{\circ}$. Inset, locations of Lake Huguang Maar, Hulu cave and the Chinese loess plateau.

Figure 2: Comparison of the monsoon sensitive sedimentary records from Lake Huguang Maar with other climate records.

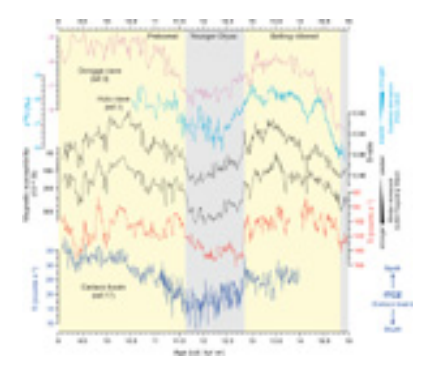

These are from the Cariaco basin ${ }^{17}$, in the southern Caribbean off Venezuela, and Hulu and Dongge caves $^{1,2,3}$. The Bølling-Allerød, Younger Dryas and Preboreal are highlighted. 
Figure 3: The Lake Huguang Maar palaeoclimate records during the past 4,500 yr in the context of major events in the cultural history of China.

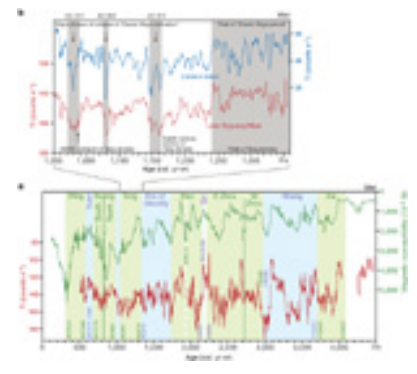

a, Major changes in Chinese dynasties ${ }^{30}$ occurred during dry phases, as indicated by the titanium and magnetic susceptibility records from Lake Huguang Maar and applying the observed anti-correlation between the winter and summer monsoons, while the described 'golden ages ${ }^{30}$ tended to occur during wet phases. b. Comparison of titanium records from Lake Huguang Maar and the Cariaco basin. The shared features of the two climate records as well as the similar timing of Chinese ${ }^{30}$ and Mayan ${ }^{4,5}$ societal changes suggest a role for coherent climate changes (that is, ITCZ migration) across the Pacific in the events of widely dispersed civilizations. 